V. - ABSORPTION

\title{
ÉTUDE DES VARIATIONS DE DÉBIT DANS LE SYSTÈME PORTE DIGESTIF DU PORC
}

\author{
A. RÉRAT \\ avec la collaboration technique de P. VAugelade \\ Station de Recherches sur l'Élevage des Porcs, \\ Centre national de Recherches zootechniques, I. N. R. A., \\ 78 - Jouy-en-Josas
}

Une méthode d'étude a été mise au point, permettant de connaître le débit sanguin dans la veine porte, ses variations et les facteurs susceptibles d'intervenir. Le principe de la méthode utilisée consiste à créer un champ magnétique de faible intensité, perpendiculairement au courant sanguin et à mesurer la variation de la force électromotrice induite par le déplacement du sang, variation proportionnelle à la vitesse de ce dernier (KoLIN, I952). Dans ce but, un débitmètre électromagnétique Medicon $\mathrm{K} 2$ ooo a été utilisé avec des sondes en "epoxy " modèle $\mathrm{K}$, de I 2 à $\mathrm{I}_{4} \mathrm{~mm}$ de diamètre intérieur selon le cas. Ces sondes ont été mises en place autour de la veine porte, successivement chez to porcs de race Large White, de poids vif compris entre 30 et $40 \mathrm{~kg}$ et maintenus pendant des périodes d'enregistrement continu oscillant entre 8 et go jours.

On constate ainsi qu'il existe une très forte variabilité du débit de la veine porte et quatre facteurs de variation ont pu être précisés :

- Cycle circadien : le débit porte est minimum pendant la nuit et maximum dans l'après-midi, les extrêmes étant séparés par des écarts de $3^{\circ} \mathrm{p}$. Ioo. La forme de la courbe moyenne d'évolution journalière est modifiée lorsque change le nombre quotidien de repas.

- Repas : lors de chaque repas, il se produit une augmentation plus ou moins marquée du débit de la veine porte (entre 7 et 20 p. Ioo par rapport au débit enregistré au repos).

- Poids vif : le débit moyen d'une journée augmente avec le poids vif de l'animal; il semble rester constant lorsqu'on l'exprime en fonction du poids vif.

- Variation individuelle : on enregistre sur une journée des débits oscillant entre $40 \mathrm{ml} / \mathrm{kg} / \mathrm{mn}$ et $55 \mathrm{ml} / \mathrm{kg} / \mathrm{mn}$ d'un porc à un autre.

Il ressort de ces études que le débit dans la veine porte ne peut être prévu de façon précise, ni à partir du poids vif de l'animal, ni d'après l'heure de la journée. L'étude quantitative de 
l'absorption des nutriments nécessite donc la mise en ouvre simultanée de la technique ici décrite et de la technique de prélèvement de sang porte précédemment publiée (ARSAC et RÉRAT, I962).

\title{
SUMMARY
}

\author{
STUDY OF THE VARIATIONS IN THE FLOW RATE \\ OF THE DIGESTIVE PORTAL, SYSTEM IN THE PIG
}

A method for studying the blood flow rate in the portal vein, its variations and the factors liable to interfere has been developed. The principle of the method used consists of the creation of a magnetic field of low intensity, perpendicular to the blood flow, and measuring the variation in the electromotive force induced by the circulation of the blood. This variation is proportional to the blood flow rate (KolIN, 1952). An electromagnetic flowmeter, Medicon K 2 ooo, was used, with model $\mathrm{K}$ flow probes (internal diameter : $\mathrm{I2}-\mathrm{I}_{4} \mathrm{~mm}$ ). These flow probes were placed successively around the portal vein of 10 Large White pigs weighing between 30 and $40 \mathrm{~kg}$ and maintained during the periods of continuous recording lasting between 8 and 90 days.

A very important variation in the portal vein flow rate and the following four factors governing these were observed :

- Circadian cycle : the portal flow rate is at a minimum during the night and at a maximum in the afternoon, the extremes being separated by differences of $30 \mathrm{p}$. Ioo. The pattern of the curve of the daily mean variation is modified when the daily number of meals changes.

- Meal : a more or less pronounced increase of the portal vein flow rate occurs at each meal (between 7 and $20 \mathrm{p}$. Ioo in comparison with the flow rate recorded between meals).

- Live weight : the daily mean flow rate increases with the live weight of the animal ; it seems to remain constant when expressed in relation to the live weight.

- Individual variation : daily recordings of the flow rate show differences from one animal to another between $40 \mathrm{ml} / \mathrm{kg} / \mathrm{mn}$ and $55 \mathrm{ml} / \mathrm{kg} / \mathrm{mn}$.

These studies show that the flow rate of the portal vein cannot be precisely predicted, either from the live weight of the animal or from the time of day. Thus, the quantitative study of the absorption of nutrients requires the simultaneous use of the technique described here and of the technique of portal blood sampling previously described (ARSAC and RERAT, 1962).

\section{RÉFÉRENCES BIBLIOGRAPHIQUES}

Arsac A-M., Rerat A., 1962. Ann. Biol. anim. Bioch. Biophys., 2, 335-343.

Kolin A., 1952. Rev. Sci. Instr., 23, 235-242. 